\title{
AN UNSOCIAL ELEMENT IN RELIGION
}

\author{
ERNEST R. GROVES \\ New Hampshire State College
}

Knowledge of narcotic drugs did not await the advent of civilized man. Savage man, perhaps primitive man also, long ago made the discovery of the pleasures obtained from narcotics. Ratzel, in his History of Mankind, tells us that "every race in all parts of the earth has hit upon some means of enjoying caffeine compounds and alcohol. Tobacco is not the only narcotic herb that is smoked. The methods of chewing betel and coca are strikingly alike." Modern psychology has revealed the causes of this almost universal human craving for narcotics.

It is no figure of speech to call certain mental states narcotic in character. Without doubt the mind in its contact with its environment is invigorated by some of its experiences and deadened by others. This contrast between opposite types of mental states seems fundamental. One expands the body, the other causes it to retreat. Some of the experiences that belong to the states of the latter class are clearly narcotic in their characteristics. These mental states of thinking and feeling afford somewhat the same peculiar satisfaction that follows the use of narcotic drugs. Relief is had from the oppressive inhibitions. Freedom is given to fancy. The being revels in the fictitious wealth of subjective creation. The tyranny of rigid fact is for the moment forgotten, and the life enjoys to the full its opportunity to remake the world according to its wishes. Limitation, disappointment, and sorrow are driven from the life, while happy fancy takes possession.

These states that remove from the mind its self-consistency, that cover reality with the deceit that is born of cowardly fear, are certainly found in religious experience. Men there are who turn to religion for protection from the unbearable facts of life. They look to religion for a removal of their keen sensitiveness to cruel

${ }^{x}$ Vol. r, p. 93. 
fact, they drink into their souls a numbing spiritual potion as other men for much the same purpose take physical poison. For such men and women religion has its appeal in its supremacy over crude fact, in the chance it gives for the self to exploit his deep cravings that are coerced by a law-abiding universe. Religion has for the defeated and distracted individual the function that we know in these modern days belongs especially to the neurosis. It affords a refuge, at what cost matters not, from the bitter facts of life.

It is this opportunity that religion offers those who court fancies that discloses its moral danger and its social weakness. What religion may do for the person depends upon the motive that he brings into his religious experience. It may withdraw him from real life and give him an improper security and an unhealthy calm of soul. It may give him the passion for personal fulfilment, the hunger for social service, the virile eagerness to know the facts of human life unadulterated by personal desire. It is only among the latter class of the religious that the spiritual life can be expected to contain moral dynamic. It would be extreme to withhold from men and women who find the world of fact too much for them the comfort of religion, but, nevertheless, this relief has in it the dangers of narcotic experiences. A return later to the harder facts of everyday striving may become difficult. Social courage comes from the religious souls who get from their religion a love for the grapple with life, who attack that from which their sickly brother retreats. This distinction between religious motives the social reformer must take deeply to heart. His business it is to develop a healthy religion that can be put to use.

We are told that the organization of religion provides the typical moral engine in savagery. ${ }^{I}$ Lester Ward, the great sociologist, asserts that in its origin religion was especially related to morality and had its function in the necessity of making the demand of good conduct forceful. It is here, he writes, "where morals and religion most closely approach each other, for at the beginning all religion was race perception (Gattungsempfindung), and the creation of gods whose supposed will is thwarted by conduct dangerous to the race was simply a means of enabling the feeble mind of the

× Todd, The Primitive Family as an Educational Agency, p. 172. 
individual to distinguish right from wrong conduct." not evidences, however, of a narcotic tendency in religion among very primitive people? Leonard in his remarkable study of West African religion reveals an attitude of mind which is far from being that of which Ward speaks. Leonard states. ${ }^{2}$

It has been my endeavour throughout these pages to convince the reader that life, so far as these people are concerned, although naturally and intensely appreciated, is valued cheaply, or at least that it is not rated so highly as it is in civilized communities. This, when the absolutely precarious nature of an existence governed by inexorable and unexpected conditions is comprehended, will be easily understood. Not only this, however, but the principle that life is spiritual, and as such continuous and recurring, is bound to decrease the value of an essence which, although mobile and fleeting, is all the same vital and immortal.

But, apart from these weighty and practical considerations, there is another and equally weighty reason that accounts for a philosophy which is indicative, not only of a lack of moral fibre, but of a supreme indifference and contempt for life, which in a natural people is not altogether easy to reconcile.

The explanation, however, is simple. Spiritualism, in a word, is responsible for this morbid and seemingly inexplicable philosophy, and the fact that this belief is not, as we call it, supernatural, but a going outside of, a departure from Nature, i.e., a revolution or something unnatural, explains with sufficient and explicit clearness its otherwise extremely incomprehensible characteristic.

It is interesting that the writer declares this spiritual interpretation of life morbid because of its indifference to the real facts of nature.

Tolstoy has said that there was a time in his experience when the aspiration of his whole being was to get out of life. This experience, in some degree at least, is common enough to be well understood. There is an emotional rebellion against the hard circumstances of life. It is necessary to notice that the situation may be as easily met, however, by getting rid of the uncomfortable facts as by leaving earthly existence. Religion can best provide such a suffering mind with the magic that can remove the brutal facts to make room for the eagerly desired fancies. Royce has described in his usual vigorous manner this unwholesome attitude of mind: ${ }^{3}$

It would be atrocious if the consequences of sin were to prove too grave. If we cannot reconcile a given supposition with the mercy of God, then the

× Pure Sociology, p. $42 \mathrm{x}$. ${ }^{2}$ The Lower Niger, and Its Tribes, p. 198.

3 The Spirit of Modern Philosophy, p. 442. 
supposition must be false. And all this reasoning, when more fully analyzed, usually proves to mean, in the minds of those who use it, a sense that if there is any spiritual order in this universe it must be an order that does not permit very many ills, and that, above all, does reward quickly all good efforts. Thus reasoning, the religious optimist of the day finds his comfort in an assurance of the kindliness of God, of the early triumph of morality, and of the general peacefulness of the universe, an assurance, I say, which, on the whole, I can not share.

It is generally true in highly cultured modern life that women have less opportunity to indulge in physical narcotics than men. There is, however, no reason to suppose that women need narcotic relief less than men. Indeed, the tendency toward psychopathic diseases among women, disorders which frequently appear to have the function of relief, would make one think that women are as likely to need narcotics as men. "The psychological trouble in neurosis, and neurosis itself, can be considered as an act of adaptation that has failed," says Jung: ${ }^{x}$ The neurosis illustrates the ostrichlike function which results in the exclusion of the pain-producing mental processes from consciousness, of which Ernest Jones writes. ${ }^{2}$ May it not be that many women too healthy-minded to accept psychopathic relief, unable to indulge in narcotic drugs with the freedom of men because of the fact that custom frowns upon such habits among women, as smoking for example, turn to religion for the needed relief from the hardness of their life experiences? Such women would naturally show a greater willingness to separate religious aspiration from positive moral acting than is common among men. To assume this does not contradict the fact that most women in our churches are seriously interested, when opportunity is given them, in social service.

The socially dangerous character of the narcotic element in religion can hardly escape one. It appears, for example, in asceticism. Asceticism attempts to cut the person away from his environment that he may not need morally to adjust himself to it. "Here asceticism comes in," writes Sumner, "for the thing to be renounced is not the errors and faults of earthly life, but earthly life itself (worldliness). The man must turn away from

I Analytical Psychology, p. 234.

2 Psycho-analysis, p. 7 . 
everything which would entangle him in the interests of mortal life and the appetites of the body," It is an interesting fact that this tendency toward asceticism appears often after the individual in his earlier career has greatly failed morally in his efforts to adjust himself to his environment. This suggests that there is often a lack of moral confidence in such cases which turns the individual toward asceticism, just as the drug fiend looks to his narcotic for a happy, even if temporary, escape from his sense of past failure and from his fears of the future. When under a morbid religious attitude a life assumes the ascetic policy, there is no promise of social good, for the social failure of asceticism is not open to controversy. ${ }^{2}$

The danger of the narcotic element in religion may show itself in a craving for self-suppression. In this morbid experience effort is made to dull the activity of the self rather than to trifle with the objective facts. Leonard has illustrated this state of mind in a most interesting manner. He writes:

Many of the more intelligent natives whom $I$ have questioned on this subject have one and all briefly answered my queries somewhat in the following words: "The reason that many among us have for wishing that their souls may be allowed to pass into trees or objects made of clay, wood, or stone, is that they have experienced a very hard and troublous life. Dreading, therefore, that they may be reborn again only to undergo perhaps another life of woe and misery, they endeavour to obtain, by a rigid course of offering and sacrifice, and eventually to secure through the mediation of their ancestors, a spiritual transfer to those bodies which they have selected for themselves." 3

Mysticism surely illustrates this desire on the part of some to decrease their sense of self by making use of religious opportunity to revel in the most intoxicating form of mental states. It is needless to call attention to the general fact that the mystic plays no heroic part in the moral contest of his time. He lifts himself so far above the usual plane of life that he little feels the demand for real brotherhood spirit and practical, constructive social service. He becomes "God-intoxicated," as Spinoza by some authorities has been charged with being.

Folkways, p. 6r2.

${ }^{2}$ Groves, Moral Sanitation, pp. I 16-18.

3 The Lower Niger and Its Tribes, p. $22 \mathrm{I}$. 
The other-worldliness of morbid religious people explains the reason why science is so often looked upon with suspicion. Science takes the world on faith and regards facts as serious. It assumes the value of human experience and attempts to understand it. It investigates objective fact for the purpose of control. All this emphasis upon the meaning of actual experience irritates those who covet other-worldliness. The antagonism, even when it gathers about some specific discovery or theory of science, is most deeply hostile to the claims and methods of science in general. It likes earthly matters to receive less attention and to be treated with less confidence. History abounds with instances of this opposition to science on the part of people who are other-worldly in this habit of mind, and the hostility is ever finding new opportunity to attack science.

The narcotic element in religion is an unhappy fact for social progress. The better living together of men and women requires the best possible use of moral and social resources, and so it is unfortunate that such strong emotionalism and serious religious commitment as is represented often by those who cling to the narcotic in religion cannot, because of its very character, be put to service. Social improvement has to depend upon the other type of religious believer. Social progress comes from the religion that is the moral engine. One's moral confidence in religion is determined by which type of religion one finds characteristic. Modern life by a sense of the sanity of wholesome idealism seems more and more to be placing emphasis upon the productive type of religious experience. This has been pointedly expressed by the statement that the chief hygienic idea with regard to religion is that it should be tied indissolubly to duty. It is early experience perhaps that decides whether religion and moral service are to separate or to keep splendid fellowship through life. Proper training of the child should prevent the individual in later adult life from turning to religion for narcotic experiences. He who seeks in religion its narcotic element counts little in the struggle for social progress.

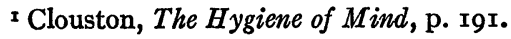

